\title{
Az akutfájdalom-kezelő szolgálat szerepe a mütét utáni fájdalomcsillapításban
}

\author{
Lovasi Orsolya $^{1}$ - Lám Judit dr. ${ }^{2}$ - Kósik Nándor dr. ${ }^{3}$ \\ ${ }^{1}$ Semmelweis Egyetem, Rácz Károly Doktori Iskola, Budapest \\ ${ }^{2}$ Semmelweis Egyetem, Egészségügyi Közszolgálati Kar, Egészségügyi Menedzserképző Központ, Budapest \\ ${ }^{3}$ Heim Pál Országos Gyermekgyógyászati Intézet, Budapest
}

\begin{abstract}
A perioperatív fájdalomcsillapítás kérdésköre jelentős kihívás az egészségügyi ellátást végzők számára. A nem jól ellenőrzött, mútét utáni fájdalom szövődményekhez vezethet. A világszerte elterjedt szervezési módszer, az 'Acute Pain Service' teamek kialakítása bizonyítottan növeli a posztoperatív fájdalomcsillapítás eredményességét. Összefoglalónk célja, hogy közlemények alapján leírja az akutfájdalom-kezelő szolgálat fogalmát, szervezeti struktúráját, minőségi kritériumait és a külföldön történt bevezetés modelljeit. Több adatbázisban történt keresés után PICO-technikával szisztematikusan áttekintettük az irodalmat, és 263 absztrakt került értékelésre. A világ számos országában múködtetik a szolgálatot, alapvetően háromféle múködési struktúrában. A személyzet aneszteziológusból és fájdalomterápiára specializálódott ápolószemélyzetből áll. A teamek múködésének leírására 5 minőségi kritériumot hoztak létre, de fontos szerepe van a szolgálatnak a betegek és a személyzet oktatásában és a fájdalomterápiás protokollok kialakításában. Javasoljuk, hogy hazánkban is készüljön felmérés a szolgálatok múködéséről és a minőségi kritériumok érvényesülésérôl a posztoperatív fájdalomcsillapítási ellátás terén.
\end{abstract}

Orv Hetil. 2020; 161(15): 575-581.

Kulcsszavak: posztoperatív fájdalomcsillapítás, akutfájdalom-kezelő szolgálat, fájdalomkezelő nővér

\section{The role of acute pain service in postoperative pain relief}

Perioperative analgesia is a major challenge for healthcare providers. Not well-controlled pain after surgery can lead to complications. The worldwide spread of acute pain service (APS) teams has proven to increase the effectiveness of postoperative pain management. This publication aims to describe the concept, structure, quality criteria, and implementation models of acute pain management services based on relevant publications. A systematic literature review was conducted in the relevant databases by the PICO technique, and 263 abstracts were evaluated. The service is available in many countries around the world, basically in three functional structures. The team consists of anesthesiologists and nursing staff specialized in pain therapy. There are 5 quality criteria for describing how the teams work, but service plays an important role in educating patients and staff and developing pain-therapy protocols. We recommend a survey-based evaluation of the current status of APS and the fulfilment of quality criteria in the field of postoperative pain management in Hungary.

Keywords: postoperative pain relief, acute pain service, pain nurse

Lovasi O, Lám J, Kósik N. [The role of acute pain service in postoperative pain relief]. Orv Hetil. 2020; 161(15): $575-581$.

(Beérkezett: 2019. november 3.; elfogadva: 2019. december 28.)

\section{Rövidítések}

APS = (Acute Pain Service $)$ akutfájdalom-kezelő szolgálat; CPSP $=($ chronic postsurgical pain) krónikus posztoperatív fájdalom; IPS = (in-hospital pain service) kórházi fájdalomkezelő szolgálat; IV-PCA = (intravenous patient-controlled analgesia) intravénás beteg által kontrollált analgézia; $\mathrm{OECD}=($ Organisation for
Economic Co-operation and Development) Gazdasági Együttmúködési és Fejlesztési Szervezet; PICO = (patient $/$ problem, intervention, comparison/control, outcome) beteg/probléma, beavatkozás, összehasonlítás/kontroll, kimenet; USA = (United States of America) Amerikai Egyesült Államok; WHO = (World Health Organization) Egészségügyi Világszervezet 
A mütét utáni fájdalomcsillapítás jelentős kihívás elé állítja az ellátást nyújtó orvosokat, egészségügyi szakdolgozókat. Az első posztoperatív napon a súlyos fájdalom prevalenciája $39 \%$ is lehet. Bizonyos sebészeti beavatkozások után a betegek több mint 75\%-ának van közepes vagy súlyos fájdalma $[1,2]$. Egy 2250 beteget vizsgáló tanulmány szerint a mütéten átesett betegek $50 \%$-a azt jelezte, hogy nem volt számára megfelelő a posztoperatív fájdalomterápia [3].

A mútét utáni fájdalmat sokáig betegségtünetnek tekintették, amelyet el kell fogadni. Csak a narkózis sikeres bevezetése után változott meg az a hozzáállás, hogy nemcsak az intraoperatív, hanem a posztoperatív fájdalmat is kezelni szükséges, mivel az akut fájdalom nemcsak önálló tünet, hanem a kezelés sikerességét is negatívan befolyásolja [4].

A nem jól kontrollált, akut fájdalomban szenvedő betegeknél olyan jelentős pszichológiai zavarok alakulhatnak ki, mint a szorongás, a depresszió és az alváshiány. Emellett a refrakter akut fájdalom korrelálhat a krónikus posztoperatív fájdalom (CPSP) kialakulásával, valamint növeli a kórházi tartózkodás hosszát, és az újrafelvételek egyik gyakori oka is [5].

A krónikus fájdalom kialakulásának jelentőségét támasztja alá Zaccagnino és mtsai kutatása, miszerint a betegek 10-70\%-ánál alakul ki valamilyen mértékű krónikus, mütét utáni fájdalom, az elvégzett mútét típusától függően [6].

A magas színvonalú ellátás eléréséhez szükséges, hogy orvosok és ápolók képzett csapata együtt dolgozzon, és hatásos ellátást biztosítsanak a mütétek után lehetséges, sokszínú akutfájdalom-szituációkban. A kórházi posztoperatív fájdalomkezelés előmozdítására olyan stratégiák bizonyultak eredményesnek, mint a fájdalom értékelése, a következetes fájdalomcsillapító terápia, a személyzet és a betegek oktatása a fájdalomkezelésról és az 'Acute Pain Service' (akutfájdalom-kezelő szolgálat, APS) szervezése [7]. Az első javaslatot az APS kialakítására 1976-ban publikálták. Ezt követően a Washingtoni Egyetem altatóorvosai 1985-ben elsőként hozták létre az APS-t az Egyesült Államokban, majd 1988-ban közölték az első APS felépítését, amelyet altatóorvosok múködtettek. Ezután sok szervezet kezdeményezte APS-protokollok és -irányelvek létrehozását, például Ausztráliában és az Egyesült Királyságban is, bár más elvek alapján, mint az USA-ban. Angliában gyorsan növekedett az APS-ek aránya: míg 1990-ben csupán a kórházak 3\%-ában, 2004- ben már a 84\%-ukban múködött fájdalomkezelő szolgálat a szigetországban [8].

Az akutfájdalom-kezelő szolgálatoknak bizonyítottan számos pozitív hatását írták már le a korábbi években, úgymint a posztoperatív állapot javulása, a mellékhatások (hányás, hányinger) és a betegek fájdalompontszámainak csökkenése, a betegelégedettség és a betegbiztonság növelése és a kórházi tartózkodás hosszának rövidülése [2, 9-11]. Ma a szolgálat múködtetésének eredményessége a szakirodalomban nem kérdőjeleződik meg, sokkal inkább nehéz választ találni az optimális szervezeti-müködési struktúra kialakítására.

A nemzetközi elterjedtség és evidenciák szerinti eredményes múködés ellenére Magyarországon ez idáig keveset tudunk az APS-ek létezéséről, múködéséről és szervezési tapasztalatairól.

Tanulmányunk célja az 'Acute Pain Service' fogalmának tisztázása, a szolgálat múködési struktúrájának leírása, az APS által végzett főbb tevékenységek bemutatása, a szolgálaton belül az orvosok és szakdolgozók feladatmegosztásának vizsgálata és a bevezetés külföldi modelljeinek és akadályainak áttekintése a rendelkezésre álló szakirodalom alapján. Összefoglalónk kiindulópontot jelenthet a hazai APS-teamek kialakításához, múködésük megszervezéséhez vagy a már múködő teamek tevékenységének fejlesztéséhez.

\section{Módszer}

Szisztematikus irodalomkutatást végeztünk. A keresési kifejezéseket a PICO-technika szerint állítottuk fel [12, 13]. A jelzett technikával készült keresési kifejezéseket az 1. táblázatban ismertetjük.

A PubMed, a Google Scholar és a Scopus adatbázisokban történtek a keresések, a 2010 és 2018 közötti időszakra, alapvetően angol nyelvü cikkekre vonatkozóan, de néhány korábban íródott, alapmúnek tekinthető - kiemelkedő fontosságúnak tartott - irodalmi hivatkozás is bekerült a dolgozatba. Keresésünk a 'review' és 'nem review' típusú cikkekre egyaránt kiterjedt. A keresésben az „and”, „not” és „or” operátorokat használtuk az összefüggések feltárására, korlátozására. Az APS szerepét elsősorban a felnőtt, műtét utáni ellátásra vonatkozóan kívántuk tisztázni, így keresésünk a palliatív, illetve onkológiai ellátásra vonatkozóan kizárásokat tartalmazott. Ezenkívül a kutatási célhoz illeszkedő egyéb cikkek kézi keresés eredményeként az értékelésbe bevonásra

1. táblázat | Keresőkifejezések használata PICO-technikával

\begin{tabular}{lllll}
\hline & Probléma & Beavatkozás & Összehasonlítás & Eredmény \\
\hline Keresókifejezés & Postoperative pain & Acute pain service, pain nurse & Nem releváns \\
\hline Alternatív kifejezés & Acute postoperative pain & $\begin{array}{l}\text { Postoperative pain service, } \\
\text { acute pain management }\end{array}$ & Nem releváns & Efficacy \\
\hline
\end{tabular}

PICO = beteg/probléma, beavatkozás, összehasonlítás/kontroll, kimenet 
kerültek. A duplikátumszưrés után fennmaradó cikkek tartalmát előre meghatározott szempontok szerint vizsgáltuk, miszerint tartalmaznak-e információt az APS definíciójára, céljaira, kialakított struktúrájára, múködési rendjére, az általuk végzett tevékenységre, a fenntartási költségekre, akadályokra vonatkozóan.

\section{Eredmények}

Összesen 263 értékelhető és hozzáférhető cikket találtunk (PubMed: 69, Google Scholar: 73, Scopus: 32, egyéb szakirodalmi keresés: 77, magyar nyelvú szakirodalom: 12). A duplikátumszűrést követően maradt 139 értékelhető tanulmány (PubMed: 33, Google Scholar: 45, Scopus: 3, egyéb szakirodalmi keresés: 46, magyar nyelvú szakirodalom: 12). Az absztraktszúrés után relevánsnak ítélt közlemények száma 92 volt (PubMed: 23, Google Scholar: 36, Scopus: 1, egyéb szakirodalmi keresés: 30, magyar nyelvű szakirodalom: 2). A jelen dolgozatban a legrelevánsabbnak ítélt közlemények (összesen 33 angol nyelvü, 3 német nyelvú és 1 magyar nyelvű mú) eredményeit összegezzük. A bevont cikkek korábban említett szempontok szerinti vizsgálata után eredményeinket több alfejezetben tárgyaljuk, bemutatva az APS-ek nemzetközi elterjedtségét, definícióját, múködésük legfontosabb célkitűzéseit, a kialakítás modelljeit, rendelkezésre állását, fájdalomfelmérési és oktatási, kutatási, minőségfejlesztési tevékenységét, valamint költségeit.

Nasir szerint az APS kialakításának valószínűsége közvetlen összefüggésben állhat a kórházi mérettel: >1000 ágy (100\%), 501-1000 ágy (93,7\%), 200-500 ágy (79\%) és <200 ágy (52,2\%) [14].

Egy korai, 1991-es kanadai felmérés szerint az APS-t bevezették az oktató kórházakban, míg más kórházak egyharmad része még csak dolgozott ezen. Az 1994 és 1996 közötti adatok azt mutatták, hogy az ausztrál nagy intézmények 77\%-a múködtette a szolgálatot [15]. Németországban az 1980-as évek közepén jelentek meg az első publikációk fájdalomszolgálat kialakítására vonatkozóan, majd további mérföldkő volt a „pain nurse” koncepció bevezetése, ami egy fájdalomterápiára specializálódott ápolószemélyzetet jelent [3]. Egy 2016-ban végzett német felmérésben azt találták, hogy a kórházak 81\%-a múködtetett APS-t [16].

Olaszországban az APS-ek száma még alacsonyabb, mint más európai országokban [8, 17], 2012-ben a kórházak 58,5\%-ában múködött ilyen szolgálat [14, 18].

Egy 2015-ben készült holland tanulmány leírja, hogy a kórházak 90\%-ában múködik APS [2].

Dániában az APS-ek aránya az egyetemi kórházakban 52-71\% között, a regionálisan múködő kórházakban 8-40\% között mozgott 2009-ben [19].

Portugáliában 2012-ben létrehoztak egy irányelvet, mely szerint az APS megszervezése kötelező minden sebészeti tevékenységet végző kórházban. Az akcióterv bevezetése után elindított felmérésekben azt találták, hogy az intézmények 47,7\%-ában múködött APS [20].
Egy 2014-ben, Indiában végzett felmérés eredményei szerint a megkérdezett kórházak 47\%-ában múködik APS, amelyet fóleg aneszteziológusok vezettek [21].

Az új-zélandi kórházak 19,4\%-ában volt 2002-ben formálisan kialakított APS [22].

Az irodalomkutatás alapján nem találtunk a hazai gyakorlat leírására vonatkozó közleményt a témában.

\section{Az APS jellemzői, céljai, szerkezete, rendelkezésre állása, gazdasági vonatkozásai}

Általánosságban az APS egy olyan elkötelezett teamet jelöl, amely a kórházakban az akut, mútét utáni fájdalom csillapításának területén az eredményes és biztonságos ellátást segíti [2].

Más közlemények szerint aneszteziológus vezetésével, magas kompetenciával rendelkező szakdolgozók nyújtják a posztoperatív fájdalomcsillapítási ellátást, és ez a multidiszciplináris csapat speciális fájdalomkezelő nővérból és tanácsadókból áll $[8,23]$.

Jain és mtsai az akutfájdalom-csillapítási szolgáltatásokat úgy alakították ki, hogy - a lefektetett fájdalomprotokollok és irányelvek alapján - egy meghatározott, egészségügyi személyzet által vezérelt szolgáltatást hoztak létre, amely felméri és kezeli a fájdalmat és a mellékhatásokat, s mindezeket 24 órán keresztül teszi [21].

Goldberg szerint az APS lényege, hogy az orvosok és nővérek képzett és hozzáértő csapata együtt dolgozzon, és gyors, hatásos ellátást biztosítsanak a sokféle akutfájdalom-szituációban [7].

Az előző meghatározásokkal összhangban az APS célját az akut és a krónikus posztoperatív fájdalom intenzitásának csökkentésében foglalhatjuk össze [24, 25].

Az APS céljai Tawfic megfogalmazásából érthetők meg a leginkább, amely szerint:

- egy meghatározott csapat 24 órás megfigyelést/konzultációt biztosít fájdalom fennállása esetén,

- együttmúködik a sebészekkel és az osztályos nővérekkel a fájdalom menedzsmentje terén, képzi a rezidenseket és az ápolókat,

- növeli a beteg tudását és tudatosságát a fájdalomcsillapítás lehetôségeivel és előnyeivel kapcsolatban, vizsgálja a fájdalomcsillapítás költséghatékonyságát,

- új módszereket tanulmányoz és alkalmaz a szakterületen $[15]$.

\section{Az APS-modell lehetséges szerkezeti felépitése}

Ahogyan az APS definíciója sem volt teljesen egységes az egyes szerzők szerint, úgy a szakirodalom több lehetőséget fogalmaz meg a csoport felépítését illetően is.

Ready volt az első, aki leírta a team szerkezetét, amely kizárólag altatóorvosból állt. Ö logikusnak találta a gondolatot, hogy az altatóorvosok biztosítsák a fájdalomcsillapítást [15]. 
Az APS-ek múködtetésében más tapasztalatok szerint is kulcsszerepe van az aneszteziológusnak. Svédországban fejlesztették ki azt az alacsony költségvetésű modellt, amely nóvéralapú, de aneszteziológus felügyeli. Ily módon az akutfájdalom-ápoló (acute pain nurse) közvetít a beteg és az aneszteziológus között, például telefonon referál az orvosnak a fájdalommal kapcsolatban, értékeli a betegek gyógyszeres fájdalomcsillapítását és annak mellékhatásait $[7,26]$.

Eredményeink alapján a legtöbb szolgálat nővéralapú, de a felügyeletet egy 'supervisor' aneszteziológus látja el, így vezetve a többi egészségügyi szakembert $[2,6,15$, 20, 27-29].

Egy olasz tanulmány az APS-ek szervezésének egy harmadik lehetőségét veti fel. Ennek a szolgálatnak a menedzselését aneszteziológus rezidensek végezték. Minden nap reggel 8 és este 8 között egy rezidenst kifejezetten az APS-be jelöltek ki a betegellátásra [17].

\section{Az APS tevékenységei, rendelkezésre állása, funkciója, a fájdalom kezelésére alkalmazott személyzet kijelölése}

A kijelölt személyzet meghatározása meglehetősen sok nehézségbe ütközik mindenhol. Az APS létrehozásának első lépése a tagok azonosítása és fenntartható munkafolyamatok kialakítása [25]. Egy német vizsgálatban aneszteziológiai osztályok vezetőit kérdezték meg kérdőíves vizsgálattal az APS szervezetére, személyzetére vonatkozóan. Minőségi kritériumok alapján (a posztoperatív fájdalom kezelésére alkalmazott személyzet kijelölése, a betegellátás szervezése éjszaka és hétvégén, írásbeli protokollok a posztoperatív fájdalom kezelésére, a fájdalompontszámok rendszeres felmérése és a fájdalompontszámok rendszeres dokumentálása) sorolták az APS-eket két alcsoportba aszerint, hogy megfelelnek-e ezeknek vagy sem. A német kórházak $81 \%$-a múködtetett APS-t, amelyek 96\%-a az aneszteziológiai osztályhoz tartozott. Az APS-be kijelölt orvosok $82 \%$-a munkáját egyéb feladataival együtt végezte, míg 9\% teljes mértékben az APS-ben dolgozott. Az ápolóknál hasonló volt az eloszlás: az APSek 49\%-ában az ápolók megosztották az APS-ben végzett tevékenységüket más feladataikkal [16]. A holland kórházak 58\%-ának van kijelölt csapata, amelynek létszáma 1-5 fö [2]. A munkaidőn túli ellátás túlnyomórészt „on-call” (telefonos hívás) módon valósult meg. Azok a kórházak, akik nem múködtettek APS-t, fooként az erőforrások, az érdeklődés és a motiváció hiányát jelölték meg [16]. Az APS általi 24 órás lefedettség a kórházak 3-5\%-ában van jelen Németországban [16], 26\%-ukban az USA-ban [14] és 22\%-ukban Hollandiában [2].

\section{Fájdalomfelmérési tevékenység}

Németországban a mütéti esetek $86 \%$-ában van rendszeres fájdalomfelmérés, amelyet az APS személyzete végez
[3], illetve más irodalmi adatok szerint is rendszeres a fájdalom felmérése mütét után $[11,24,28,30]$. A fájdalomfelmérés vonatkozásában nagyon fontos az a brit szabvány, amely a rendszeres fájdalomértékelésre vonatkozik, különös tekintettel a sérülékeny betegcsoportokra, köztük a dementiával élő betegekre [8]. Egy jordán tanulmány szerint abban a kórházban, ahol múködött APS-szolgáltatás, a betegek szignifikánsan alacsonyabb fájdalomintenzitási pontszámot jelentettek [1]. Egy holland felmérésben a betegek fájdalmának mérése úgy alakult, hogy a posztoperatív első napon a betegek 49\%ának, a második napon a 36,7\%-ának, a harmadik napon a 21,2\%-ának mérték háromszor a fájdalmát [31]. A fájdalmat az 5. vitális paraméternek kell tekinteni, ezért naponta háromszor mérni kell, és egyénileg is, ha szükséges [2]. Ugyanakkor egy német tanulmány szerint a nyugalmi fájdalmat gyakrabban dokumentálják, mint a mozgásban kiváltott fájdalmat [16].

\section{Az egészségügyi dolgozók és a betegek oktatása}

A célkitűzések sorában a fájdalommenedzsmenten túl a betegek és az egészségügyi dolgozók oktatása is hangsúlyosan szerepelt [15]. A betegek mütét előtti oktatása - a várható fájdalomról, a regionális anaszteziológiai technikákról - javítja a betegbiztonságot, növeli a betegek tudását, és csökkenti a szorongást. A betegek mellett az ápolószemélyzet oktatását is az APS-nek kell koordinálnia (a biztonságos gyógyszeradagolási gyakorlatoknak, a lehetséges mellékhatások és a nemkívánatos események kezelésének témaköreit) $[2,14,30,31]$.

\section{Minőségértékelés, protokollfejlesztés, kutatási tevékenység}

A fájdalomkezelő szolgálatok az intézményekben a tevékenységükkel érintett ellátás minőségének értékelését, a posztoperatív fájdalommenedzsment-protokollok fejlesztését, kutatási tevékenységet és rendszeres auditot végeznek [2, 30]. Egy korábbi hazai vizsgálatunkban három érintett kórházban vizsgáltuk a fájdalomkezelésre szolgáló protokollok meglétét. Megállapítottuk, hogy a bevont intézményekben létezik valamilyen szakmai protokoll a fájdalomra vonatkozóan, de a vizsgált protokollok mélysége és részletezettsége eltéréseket mutatott, és jellemző volt, hogy a posztoperatív észlelés vonatkozásában nincsenek leírt, egységes intézeti elvárások [32].

Amíg az írott, fájdalomkezelésre vonatkozó protokoll minőségi kritérium [16] és a posztoperatív fájdalommenedzsment nélkülözhetetlen eleme, addig ezek gyakorlatba ültetése Hollandiában 97\%-ban [2], az USA-ban $55 \%$-ban sikerült [14]. A formálisan szervezett, hivatalosan kialakított APS-ekkel rendelkező kórházak magasabb arányban jelentették az írásos posztoperatív fájdalomprotokoll meglétét. Az írott posztoperatív fájdalompro- 
tokollok tartalmazták a létfontosságú jelek monitorozására, a fájdalomértékelésre, valamint az IV-PCA és az epiduralis analgesia elrendelésére vonatkozó követelményeket [14].

\section{A betegellátás szervezése munkaidön kívïl}

Az APS 24 órás lefedettsége ajánlott, beleértve a munkaszüneti napokat is (úgymint hétvége és ünnepnapok). A brit kórházak 15\%-a nyújtott akutfájdalom-kezelő szolgáltatást a nappali munkaidőn kívül, míg a hétvégi szolgáltatást a kórházak 29\%-ában szervezték meg [8]. A 24 órás lefedettséget több helyen a munkaidőn kívül telefonon elérhető aneszteziológus vagy kiterjesztett hatáskörü szakdolgozó biztosította $[2,30,33]$. A kiterjesztett hatáskörü személyek bevonása klinikailag és gazdaságilag hatékony modellt hozhat, mivel az aneszteziológus irányítása alatt látogathatják a sebészeti beavatkozásokon átesett betegeket $[29,30]$.

\section{Fenntartási költségek, akadályok}

A fájdalomcsillapítási szolgáltatások szerkezetének és funkcióinak heterogenitása megnehezíti a költségek pontos megállapítását.

Egyetlen tanulmány sem hasonlította össze egymással a különböző APS-modelleket. Az akutfájdalom-szolgáltatás megvalósításának legköltséghatékonyabb módja a kórházakban a kultúra és a személyzet helyi különbségei miatt változik [34].

Sussman és mtsai egy londoni kórházban múködő fájdalomkezelő szolgálat vonatkozásában vizsgálták, hogy annak alkalmazása költséghatékony-e. A kórház egy ápolókkal ellátott, aneszteziológus által felügyelt IPS-t (inhospital pain service) múködtet. A teamtagok szubjektív észlelése rámutatott, hogy egyre növekszik a szolgálathoz nem megfelelően történő küldések száma. Nem megfelelő igénybevételnek számítottak azok az esetek, amelyek megelőzhetők lettek volna a WHO (World Health Organization) analgesiára vonatkozó „létrájához" való alkalmazkodással. A szerzők megnézték a nem megfelelő küldési gyakorlatok számát, illetve hogy azok kezelése mennyi időt vett igénybe. Azon túl, hogy ezek a humánerőforrás terhelését növelték, a nővérek fizetési kategóriájától függően a helytelen igénybevételek díja emelte a költségeket [35].

Lee és mtsai egy közleményükben nagy sebészeti beavatkozáson átesett betegek APS általi ellátását értékelték kontrollcsoporttal összehasonlítva. A szolgálat aneszteziológus által felügyelt, nővéralapú volt. Azt találták, hogy az APS költségei szignifikánsan magasabbak voltak (átlagkülönbség 46 USD/páciens), ugyanakkor a költséghatékonysági elfogadhatósági görbe azt mutatta, hogy az APS által nyújtott szolgáltatás költséghatékonyabb volt nagy hatásosságú fájdalommenedzsment nyújtása mellett [10].

\section{Megbeszélés}

A világ számos országában elterjedt szervezési módszer a mútéti fájdalomcsillapítás terén az 'Acute Pain Service' intézménye, amelynek eredményessége már bizonyított. Egy korábbi vizsgálatban összefoglalták, hogy 2002-ig mely országokban végeztek különböző nemzeti felméréseket az APS meglétével és a fájdalomfelméréssel kapcsolatban, ezt a 2. táblázatban ismertetjük [22]. Magyarországon e teamek helyzetéről még keveset tudunk, bár a hazai gyakorlattól sem áll messze a teamben történő munkavégzés, hiszen az egészségügyi ellátás során több területen alkalmazzuk ezt a szervezési módot, például a sebkezelés, a decubituskezelés vagy a táplálásterápia, az onkológia, a rehabilitáció területén. Egy hazai, három kórházban végzett, fájdalommenedzsmentre vonatkozó vizsgálat során tapasztaltuk, hogy a vizsgált kórházak egyikében sem múködött APS, de a megkérdezett orvosok 60\%-a támogatná a létrejöttét [32]. A rendelkezésre álló irodalom az APS több formáját írja le, úgymint az aneszteziológusokból álló team, valamint a skandináv modell, azaz a nővéralapú, de aneszteziológus orvos által felügyelt szolgálat [22]. A harmadik lehetséges forma a rezidensek által nyújtott, posztoperatív fájdalomcsillapítást végző modell [9]. A szakirodalom szerint a személy-

\begin{tabular}{|c|c|c|c|c|}
\hline 2. táblázat & $\begin{array}{l}\text { Az APS je } \\
\text { alapján (St }\end{array}$ & $\begin{array}{l}\text { lenléte a külö } \\
\text { amer et al., } 20\end{array}$ & $\begin{array}{l}\text { nböző országok } \\
02 \text { ) [22] }\end{array}$ & In, kivonat Stamer \\
\hline Ország & $\begin{array}{l}\text { A } \\
\text { vizsgálat } \\
\text { éve }\end{array}$ & $\begin{array}{l}\text { A válaszoló } \\
\text { kórházak } \\
\text { aránya }\end{array}$ & $\begin{array}{l}\text { APS-t } \\
\text { múködtető } \\
\text { kórházak } \\
\text { aránya }\end{array}$ & $\begin{array}{l}\text { Fájdalom- } \\
\text { felmérést végző } \\
\text { kórházak aránya }\end{array}$ \\
\hline $\begin{array}{l}\text { Európa } \\
\text { (17 nemzet) }\end{array}$ & 1993 & $\begin{array}{l}96 \% \text { (előre } \\
\text { kijelölt } \\
\text { kórházak) }\end{array}$ & $37 \%$ & $38,6 \%$ \\
\hline $\begin{array}{l}\text { Nagy- } \\
\text { Britannia }\end{array}$ & 1994 & $73 \%$ & $42,7 \%$ & $\begin{array}{l}\text { APS-t } \\
\text { múködtetők } \\
82 \% \text {-a, APS } \\
\text { nélkül: } 42,8 \%\end{array}$ \\
\hline $\begin{array}{l}\text { Német- } \\
\text { ország }\end{array}$ & 1999 & $58 \%$ & $36,1 \%$ & $\begin{array}{l}\text { APS-t } \\
\text { múködtetők } \\
63,9 \%-\mathrm{a}\end{array}$ \\
\hline $\begin{array}{l}\text { Spanyol- } \\
\text { ország }\end{array}$ & 1997 & $38 \%$ & $\begin{array}{l}\text { A } 200 \text { ágynál } \\
\text { nagyobb } \\
\text { kórházak } \\
\text { 30\%-a }\end{array}$ & $36 \%$ \\
\hline Svédország & 1994 & $87 \%$ & $13 \%$ & $\begin{array}{l}\text { Intenzív } \\
\text { osztályon: } \\
53 \% \text {, sebészeti } \\
\text { osztályon: } 33 \%\end{array}$ \\
\hline $\begin{array}{l}\text { Egyesült } \\
\text { Államok }\end{array}$ & 1993 & $54 \%$ & $42 \%$ & $\begin{array}{l}\text { Összes kórház: } \\
46 \%, \text { APS-t } \\
\text { múködtetôk } \\
84 \% \text {-a }\end{array}$ \\
\hline Új-Zéland & 1994 & $78 \%$ & $\begin{array}{l}\text { Formálisan } \\
\text { kialakított } \\
\text { APS: } 19,4 \%\end{array}$ & $\begin{array}{l}\text { Nem } \\
\text { vizsgálták }\end{array}$ \\
\hline
\end{tabular}

APS = akutfájdalom-kezelő szolgálat 
zethiány, a nem megfelelő hozzáállás, a fájdalomkezelés nem megfelelő ismerete a legfőbb akadályai az APS-ek bevezetésének. Nemcsak hazai jelenség, hogy az aneszteziológusok leterheltek a mútőben történő altatások során, és kevés szabad idejük van a műtét utáni vizitekre [21]. Az APS-ek költséghatékonyságának egyértelmû megítélése nagyon nehéz feladat. Csábító lehet az APSre kizárólag úgy tekinteni, mint költségcentrumra, de az általa nyújtott hozzáadott érték (jobb fájdalom-ellenőrzés, alacsonyabb opiátfogyasztás, gyorsabb felépülés, a bélfunkciók gyorsabb visszatérése, nagyobb betegelégedettség, potenciálisan csökkenthető kórházi tartózkodás) kényszerítő erôvel bírhat a bevezetésére, annak ellenére, hogy a szolgáltatás tőkeberuházást igényel [36]. A költségek leküzdésének egyik módja a kiterjesztett hatáskörü dolgozók felvétele, akik aneszteziológus vezetése alatt múködnek [30]. Az OECD- (Organisation for Economic Co-operation and Development) országok jó részében már folyik a kiterjesztett hatáskörü ápolók képzése, s ez már Magyarországon is bevezetésre került. Érdemes elgondolkodni azon, hogy hogyan lehet a kiterjesztetett hatáskörü ápolókat bevonni ezen részterület mûvelésébe. Tekintettel arra, hogy a világ számos pontján leírták már a szolgálatok jellemzőit, előnyeit, hátrányait [37], megfontolandó lenne hazánkban is felmérni a szolgálatok helyzetét, múködési kereteit. Ebbe az irányba történnek lépések egy klinikai kutatás során, amihez biztató kezdetet jelent a megkeresett hazai szakmai szervezetek, úgymint a Magyarországi Fájdalom Társaság és a Magyar Aneszteziológiai és Intenzív Terápiás Társaság támogatása. Az APS-ek tudatosan foglalkoznak a megfelelési kritériumok kialakításával [16], ezért jó alapot teremtenek ahhoz, hogy a hazai gyakorlatot fejleszszük, mivel hazánkban jelenleg nincs egységes és elterjedt szempontrendszer a mütét utáni fájdalomcsillapítás megfelelőségének mérésére. Ez elősegíti, hogy elhelyezzük a hazai posztoperatív fájdalommenedzsment helyzetét nemzetközi kontextusban, és láthassuk, mely területeken van még tennivaló, s mi az, amiben a nemzetközi mérce szerint is jól teljesítünk.

Anyagi támogatás: A kutatómunka elvégzéséhez és a közlemény megírásához a szerzők anyagi támogatásban nem részesültek.

Szerzői munkamegosztás: L. O.: Irodalom keresése, feldolgozása és a kézirat elkészítése. L. J.: A kutatómunka segítése, a kézirat végleges tartalmának kialakítása, mentorálás, az angol nyelvű összefoglalás elkészítése. K. N.: A kézirat orvosszakmai szempontból történő áttekintése. A cikk végleges változatát valamennyi szerző elolvasta és jóváhagyta.

Érdekeltségek: A szerzőknek nincsenek érdekeltségeik.

\section{Irodalom}

[1] Al-Tawafsheh A. The influence of an acute pain service on postoperative pain management in Jordan: a comparative case study. PhD thesis, University of Nottingham, Nottingham, 2016.

[2] Van Boekel RL, Steegers MA, Verbeek-Van Noord I, et al. Acute pain services and postsurgical pain management in the Netherlands: a survey. Pain Pract. 2015; 15: 447-454.

[3] Pogatzki-Zahn EM, Meissner W. Postoperative pain therapy in Germany. [Therapie postoperativer Schmerzen in Deutschland.] Schmerz 2015; 29: 503-509. [German]

[4] Erlenwein J, Emons M, Hecke A, et al. Prescriptions for postoperative pain therapy. [Behandlungsstandards in der postoperativen Akutschmerztherapie.] Anaesthetist 2015; 64: 218-226. [German]

[5] Pozek JJ, De Ruyter M, Khan TW. Comprehensive acute pain management in the perioperative surgical home. Anesthesiol Clin. 2018; 36: 295-307.

[6] Zaccagnino MP, Bader AM, Sang CN, et al. The perioperative surgical home: a new role for the acute pain service. Anesth Analg. 2017; 125: 1394-1402.

[7] Goldberg SF, Pozek JJ, Schwenk ES, et al. Practical management of a regional anesthesia-driven acute pain service. Adv Anesth. 2017; 35: 191-211.

[8] Rockett M, Vanstone R, Chand J, et al. A survey of acute pain services in the UK. Anaesthesia 2017; 72: 1237-1242.

[9] Wheatley RG, Madej TH, Jackson IJ, et al. The first year's expe rience of an acute pain service. Br J Anaesth. 1991; 67: 353-359

[10] Lee A, Chan SK, Chen PP, et al. The costs and benefits of extending the role of the acute pain service on clinical outcomes after major elective surgery. Anesth Analg. 2010; 111: 10421050 .

[11] Buckenmaier C 3rd, Mahoney PF, Anton T, et al. Impact of an acute pain service on pain outcomes with combat-injured soldiers at Camp Bastion, Afghanistan. Pain Med. 2012; 13: 919926.

[12] Sayers A. Tips and tricks in performing a systematic review: building a PICO search strategy. Br J Gen Pract. 2008; 58: 136.

[13] Da Costa Santos CM, De Mattos Pimenta CA, Nobre MR. The PICO strategy for the research question construction and evidence search. Rev Lat Am Enfermagem 2007; 15: 508-511.

[14] Nasir D, Howard JE, Joshi GP, et al. A survey of acute pain service structure and function in United States hospitals. Pain Res Treat. 2011; 2011: 934932.

[15] Tawfic QA, Faris AS. Acute pain service: past, present and future. Pain Manag. 2015; 5: 47-58.

[16] Erlenwein J, Koschwitz R, Pauli-Magnus D, et al. A follow-up on acute pain services in Germany compared to international survey data. Eur J Pain 2016; 20: 874-883.

[17] Borracci T, Prencipe D, Masotti A, et al. The experience of setting up a resident-managed acute pain service: a descriptive study. BMC Anesthesiol. 2016; 16: 14.

[18] Coluzzi F, Mattia C, Savoia G, et al. Postoperative pain surveys in Italy from 2006 and 2012: (POPSI and POPSI-2). Eur Rev Med Pharmacol Sci. 2015; 19: 4261-4269.

[19] Nielsen PR, Christensen PA, Meyhoff CS, et al. Post-operative pain treatment in Denmark from 2000 to 2009: a nationwide sequential survey on organizational aspects. Acta Anaesthesiol Scand. 2012; 56: 686-694.

[20] Castro AC, Martins CS. A survey of acute pain services in Portuguese hospitals: are we on the right track? Eur J Anaesthesiol. 2015; 32: 277-278.

[21] Jain PN, Bakshi SG, Thota RS. Acute pain services in India: a glimpse of the current scenario. J Anaesthesiol Clin Pharmacol. 2015; 31: 554-557. 
[22] Stamer UM, Mpasios N, Stuber F, et al. A survey of acute pain services in Germany and a discussion of international survey data. Reg Anesth Pain Med. 2002; 27: 125-131.

[23] Philips BD, Liu SS, Wukovits B, et al. Creation of a novel recuperative pain medicine service to optimize postoperative analgesia and enhance patient satisfaction. Hss J. 2010; 6: 61-65.

[24] Le-Wendling L, Glick W, Tighe P. Goals and objectives to optimize the value of an acute pain service in perioperative pain management. Tech Orthop. 2017; 32: 200-208.

[25] Kubricht V, Sevcik P. Chronic postsurgical pain in mixed surgical population. Does an acute pain service make a difference? Bratisl Lek Listy 2017; 118: 746-751.

[26] Samolsky Dekel BG. Acute pain service an open and challenging issue. EC Anaesthesia 2018; 6: 192-194.

[27] Sinatra R. Causes and consequences of inadequate management of acute pain. Pain Med. 2010; 11: 1859-1871.

[28] Schwenk W, Schinkel B. Perioperative pain therapy. [Perioperative Schmerztherapie.] Chirurg 2011; 82: 539-556. [German]

[29] Ahmed A, Yasir M. Role of acute pain service in optimizing postoperative pain relief in a tertiary care teaching hospital. J Pak Med Assoc. 2015; 65: 1164-1168.

[30] Webb CA, Kim TE. Establishing an acute pain service in private practice and updates on regional anesthesia billing. Anesthesiol Clin. 2018; 36: 333-344.

[31] Hoogervorst-Schilp J, van Boekel RL, de Blok C, et al. Postoperative pain assessment in hospitalised patients: national survey and secondary data analysis. Int J Nurs Stud. 2016; 63: 124131 .
[32] Lovasi O, Lám J. The situation of postoperative pain management in Hungary today - part 1. [A postoperativ fájdalom menedzsment helyzete napjainkban Magyarországon. 1. rész.] Nóvér 2018; 31(5): 1-40. [Hungarian]

[33] Duncan F, Day R, Haigh C, et al. First steps toward understanding the variability in acute pain service provision and the quality of pain relief in everyday practice across the United Kingdom. Pain Med. 2014; 15: 142-153.

[34] Sun E, Dexter F, Macario A. Can an acute pain service be costeffective? Anesth Analg. 2010; 111: 841-844.

[35] Sussman M, Goodier E, Fabri I, et al. Clinical benefits, referral practice and cost implications of an in-hospital pain service: results of a service evaluation in a London teaching hospital. Br J Pain 2017; 11: 36-45.

[36] Tran De Q, Krodel DJ. Optimal organization of acute pain services: at the confluence of semantics, logistics, and economics. Anesth Analg. 2018; 127: 808-810.

[37] Gordon DB, de Leon-Casasola OA, Wu CL, et al. Research gaps in practice guidelines for acute postoperative pain management in adults: findings from a review of the evidence for an American Pain Society Clinical Practice Guideline. J Pain 2016; 17: 158166.

(Lovasi Orsolya,

Dunaszentgyörgy, Mátyás király u. 11., 7135 e-mail: lovasi.orsolya@gmail.com)

Az Orvosi Hetilap 2020; 161: 360. oldalán (9. szám) megjelent OH-kvízre egy helyes megfejtés érkezett.

A beküldő: Dr. Janik Leonárd (Budapest).

A nyertesnek szívböl gratulálunk.

\author{
Nyereményét - egy, az Akadémiai Kiadó webáruházában \\ kedvezményes vásárlásra jogosító kupont - e-mailen küldjük el.
}

A cikk a Creative Commons Attribution 4.0 International License (https://creativecommons.org/licenses/by/4.0/) feltételei szerint publikált Open Access közlemény, melynek szellemében a cikk bármilyen médiumban szabadon felhasználható, megosztható és újraközölhető, feltéve, hogy az eredeti szerző és a közlés helye, illetve a CC License linkje és az esetlegesen végrehajtott módosítások feltüntetésre kerülnek. (SID_1) 